\title{
The Relationship between Teacher Candidates' Attitudes towards Teacher Credentialing Courses and Instructor Behavior
}

\author{
İbrahim Gül \\ College of Education, Ondokuz Mayss University, Turkey
}

Copyright $\mathrm{C} 2017$ by authors, all rights reserved. Authors agree that this article remains permanently open access under the terms of the Creative Commons Attribution License 4.0 International License

\begin{abstract}
The aim of this research is to examine the relationship between the attitudes of prospective teachers towards teaching profession courses and teaching staff behaviors. The research is a quantitative study. The study's study group is composed of 537 education faculty student. 'Attitude Scale towards Credentialing Courses' and 'Instructor Behavior Assessment Scale' were used as data collection tools in the research. Teacher candidates, faculty members behave adequately. However, prospective teachers' attitudes towards credentialing courses were found to be low. The opinions of the candidate teachers do not differ according to gender, department, academic achievement, mother education status, but there are differences according to the father education status and financial status of the family. A positive relationship was found between the behaviors of the lecturers and the attitudes of the prospective teachers towards the credentialing courses and it was understood that this was a predictor.
\end{abstract}

Keywords Candidate Teacher, Credentialing Courses, Teaching Staff Behaviors

\section{Introduction}

It is a well-known fact that the positive attitudes and behaviors towards the teaching profession are gained with through credentialing courses about teaching. According to Senenoğlu (1989), the basic concepts and principles of teaching are acquired through credentialing courses. These courses help teachers to develop positive attitudes towards their profession while ensuring their ability to adapt to changing conditions [1]. Credentialing courses about the teaching profession, which help teacher candidates to develop positive attitudes towards their profession, have a significant place in the education curriculum.
One of the factors that prepare teacher candidates to become good teachers is the instructors in education facilities. The instructors in education facilities contribute to the knowledge and skills of prospective teachers with their academic identity and contribute to their emotional development by serving as a role model. According to students, the qualifications and attitudes of the instructors are seen as one of the factors that affect the quality in training teachers [2]. According to instructors of education faculties, teaching in the department of education requires being a teacher [3].

Teachers who train individuals and prepare them for life must have professional competences. These qualifications, gained through pre-service training, consist of the knowledge, skills and beliefs that a teachers must possess so that they can teach effectively and efficiently $[4,5]$. In this sense, the right attitude and interest towards the profession, motivation and enthusiasm toward teaching, and mental health of teachers are among the most important factors playing a role in the success of school programs [6]. Factors such as teaching, school collaboration, interaction, guidance, student learning should be emphasized in the process of teacher training [7; $8 ; 9 ; 10 ; 11]$.

Teachers' pre-service training, carried out in the education departments, contains the knowledge, skills, attitudes and behaviors required by the teaching profession for teacher candidates. This training is generally gained through coursework on general knowledge, content knowledge and pedagogical knowledge [12]. General knowledge courses offer a holistic perspective to the prospective teacher. Content courses give them the knowledge and skills required by their field. Whatever their field is, credentialing courses provide pedagogical knowledge, that is, the art of teaching, to all prospective teachers. The content of these courses consists of learning and teaching principles, classroom management, student assessment, managing student behaviors, guidance and 
school management. In addition to this theoretical knowledge, they teach skills on how to practice the teaching profession. The achievements mentioned above are counted among competences that must be found in good teaching [13].

Teacher candidates who want to become teachers and who prefer education departments for this purpose are expected to have a high interest toward credentialing courses on teaching. Teacher candidates studying in primary school teaching and pre-school teaching have mostly expressed that credentialing courses have positive effects on their professional development [14]. According to Kara and Sağlam (2014) regarding the evaluation of teachers' pedagogical knowledge courses in terms of giving proficiency to the teaching-learning process, it was found that the candidate teachers had negative attitudes towards these courses couldn't relate these courses to themselves and profession, which led them to not favor those courses in comparison to major area courses [15].

In addition, it was indicated that the performance indicators of the teaching-learning process related to teaching professional knowledge (ÖMB) courses of instructors were reflected in the courses, with prospective teachers gaining approximately half of the performance indicators. Güleç (2012) found that the average values of the attitudes of prospective teachers in the music department toward credentialing courses about teaching have lower values than the average value of teacher candidates in history, geography, preschool, and painting departments [16]. The opinions of prospective teachers in the health department about credentialing courses were found to be more positive than teacher candidates in music and English departments. In another study, it was found that the achievement averages of the major area courses of physical education teacher candidates were higher than the credentialing courses [17].

Teacher training consists of two variables as process and product. While the process is related to the teacher's actions in the teaching process as well as the classroom activities, the product variable is related with student quality $[6 ; 18]$. According to these concepts, active participation of prospective teachers in the teaching process and classroom activities is very important. In fact, this is related to the attitudes of prospective teacher candidates towards credentialing courses. Teacher candidates are seen in some studies to not be interested in pedagogical knowledge [19; $20,21]$. In another study, the students of fine arts education found themselves to be unsuccessful in credentialing courses [22]. In some studies, the attitudes of the education faculty students towards the teaching profession were found to be positive [23, 24, 25, 26]. It seems that it is also important to note that that these courses are taught in universities as well as in general credentialing courses. In a study that revealed this situation, it is emphasized that, if the introductory educational science course is taught according to the Conceptual Design model, the students will experience positive affect and increase their active participation in the classroom [27]. Teacher behavior mostly affects the interest and participation of students in the classes [28;29].

Increasing quality of the education of teacher candidates and their qualifications refers to the product orientation of teacher training activities. Strang [30] suggests that teacher candidates should take courses on child development, teaching practices and learning for the development of teaching. Besides the ability to recognize students and school, monitoring the teaching process and classroom learning activities, ability to understand differences [31], as Mangin and Stoelinga (2010) pointed out, knowledge and skills should be gained to meet the expectations of the school and its employees [32], to increase the leadership roles of the teachers, to enrich teaching and to improve student learning. The increase in qualifications in teacher education is also related to the effectiveness of their programs in education facilities as well as the quality of instructors who conduct it $[33,34,35,36]$.

The teaching members who work in the Higher Education Institutions respect every individual's dignity and values. They endeavor to protect the freedom of democratic culture; to develop scientific research, learning and teaching; and to provide all people with equal access to those [37]. The faculty members in various faculties are professional teachers whose academic identities encompass teaching as well. The instructors who work in the education facilities and educate the teachers of the future should be aware of their roles in training and modeling by being intentional about their behavior [38] According to Carr (2000), the lifestyle, professional practices, attitudes and behaviors of the instructors have profound influence on the students $[39,40]$.

University instructors are those who are responsible for designing and developing educational programs in universities, developing student support and counseling responsibilities and creating and using appropriate teaching-learning environments for students for the purposes of their educational programs. One of the most important responsibility of the university instructors is related with the teaching and learning field is that they adapt themselves to the present conditions by innovating and developing their professional skills $[41,42 ; 35,36]$. In addition, instructors should develop themselves primarily in the areas of curriculum, teaching processes and learning processes, using educational technologies, classroom management techniques, assessment, student support and counseling.

All the behaviors of the instructors in the class have a very important effect on their students. How the behavior of the lecturer is perceived by students is the key factor and the key to success [43]. There are many similarities of the teaching-learning styles of the instructors in many ways. However, the instructors who teach credentialing courses should be particularly qualified in teaching methodology 
[44]. In some studies, the proficiency of using teaching methods of instructors was found to be low [45]. Credentialing instructors should be models for prospective teachers by demonstrating exemplary behaviors, being open-minded, and having an exemplary personality. This can be achieved by instructors carrying out their duties effectively and efficiently through a discipline related to their teaching profession programs and teaching practices [46].

In the literature on the qualifications of instructors, instructors have generally rated themselves positively in terms of teaching competencies $[47,48,49,50,51,52,53$; 54]. However, the students seem to disagree very much with this positive perception $[55,38]$. One of the important reasons for this is that the instructors did not come from the education field. It has been reported that nearly half of the instructors employed in teacher-training institutions did not receive original training to become teachers [56]. It is not known how many of these instructors are "Teaching Instructors of Teaching Profession Credentialing Courses ".

Teaching credentialing courses include courses such as Introduction to Education Science, Teaching Principles and Methods, Evaluation and Assessment in Education, Educational Psychology, Classroom Management, Special Teaching Methods, Teaching Technologies, Material Design, and Teaching Practice [57]. The main purpose of these courses is to give prospective teachers some basic credentialing skills as well as basic knowledge and skills related to the teaching profession. It is important to know what kind of attitudes they have to these courses which contribute to their professional career and prepare them for the teaching profession. In a study in which the attitudes of the prospective teachers towards the teaching profession courses were examined, the percentage of positive attitude did not exceed the percentage of negative attitude in any part of the education faculty [58]. That is, teachers' attitudes towards credentialing courses were in low levels. In another study, geography teacher candidates stated that credentialing knowledge courses are indispensable for a career in teaching [59].

According to Klausmeier and Goodwin (1966), in order to facilitate the formation of attitudes, models should be introduced, emotional experiences should be provided about the object of attitude, informational experiences should be increased, group activities should be applied, and practice should be emphasized [60]. In the formation of attitudes towards teaching profession courses, it seems that the instructors have important responsibilities. Another way to increase interest in credentialing courses is to review course content. After the curriculum is reviewed, communication between teaching staff and prospective teachers should be increased [61], that is, active methods should be preferred when teaching courses. In a study on the teaching practices and classroom behaviors of instructors, it was found that instructors fulfilled only the traditional teaching role; [62], they did not include interesting activities and notes, they encouraged their students to come prepared for the lessons, and they emphasized ineffective practices during the learning-teaching process. The importance given to credentialing courses influences the attitudes of teachers towards these courses; in other words, the students who find the teaching profession credentialing courses to be important have higher attitude scores for the teaching profession credentialing courses [63]. It is important to find out whether there is a relationship between instructors' behaviors, which are a major factor in the preparation of teacher candidates for teaching, and their attitudes towards credentialing courses. It is thought that this work will fill such a gap in the literature.

The purpose of this study is to reveal the relationship between the attitudes of prospective teachers towards teaching profession courses and teaching instructor behaviors. For this purpose, answers to the following questions were sought.

1. What are the attitudes of the teacher candidates of the education faculty towards the teaching profession lessons in different departments?

2. What are the views of the prospective teachers of the education faculty about the behaviors of the instructors in different departments?

3. Does the perceptions of the attitudes of prospective teachers towards teaching profession courses and instructors differ according to gender, department, economic status of the family, academic achievement, or education level of the parents?

4. Can instructional behaviors be regarded as a predictor of teacher candidates' attitudes towards teaching profession courses?

\section{Materials and Methods}

This study used a screening model. Screening models aim to reveal an existing situation in the real world as it exists in the reality [64]. The population of the study was taken from the students who are studying in different parts of Ondokuz Mayis University, Faculty of Education in 2016-2017 academic year. From these faculties, 537 students, 383 female and 154 male, volunteered to participate in the study. The data collection tool used in the research consists of three parts. In the first part of the study includes demographic information of the students, the second part includes the "Attitude Scale towards Credentialing Courses" developed by Ekici (2008) and the third part includes the "Instructor Behavior Evaluation Scale" developed by Durmuş and Nartgün (2003). "Attitude Scale toward Credentialing Courses" is a Likert type scale consisting of one dimension and 10 items [44, 65]. Each item has five choices such as the following: I have never attended (1), I do not agree (2), I agree (3), I 
agree (4) and I fully agree (5). The KMO score of the scale was 0.94 with a Barlett test result of 2173.67, p $<0.001$. The variance explained by the single factor was $48.157 \%$. The reliability coefficient was calculated as Cronbach's Alpha 0.80. The Instructor Behavior Scale is a Likert scale consisting of 19 items in one dimension. Each items has four choices such as insufficient (1), insufficient (2), sufficient (3) and very sufficient (4). The total variance explained by the single factor is $55.46 \%$. The reliability coefficient of the scale was calculated as Cronbach Alfa 0.92. The Kolmogorov-Smirnov test was used to examine whether the data are normally distributed. In addition, the skewness and kurtosis values were examined. Skewness values, from .022 to 1.214; The kurtosis values range from .591 to -1.404 . When the values of skewness and kurtosis are between -2 and +2 , it can be assumed that the distribution is normal $[66 ; 67]$. It was accepted that the data showed normal distribution by looking at these values. In the analysis of the data, descriptive statistics such as frequency, percentage, and arithmetic mean were used, as well as a one-way variance analysis, $\mathrm{t}$ test and regression analysis.

This section contains demographics about the candidates, attitudes of the candidates toward the credentialing courses, their opinions about the behaviors of the instructors, and opinions of the teachers were compared according to some variables. In addition, it examines whether teaching staff behaviors were a predictor of attitudes towards credentialing courses.

\section{Demographics about Prospective Teachers Participating} in the Research

The demographics of the teacher candidates participating in the survey is given in Table 1 below.

Table 1. Personal information about prospective teachers participating in the research

\begin{tabular}{|c|c|c|c|}
\hline Variable type & Variable & $\mathrm{f}$ & $\%$ \\
\hline \multirow{2}{*}{ Gender } & Female & 383 & 71 \\
\hline & Male & 154 & 29 \\
\hline \multirow{7}{*}{ Department } & Physical education & 40 & 7 \\
\hline & Fine Arts & 94 & 18 \\
\hline & Special education & 64 & 12 \\
\hline & Guidance & 73 & 14 \\
\hline & Foreign language education & 90 & 17 \\
\hline & Science Education & 50 & 9 \\
\hline & Primary school teaching & 67 & 13 \\
\hline \multirow{4}{*}{ Maternal Education Status } & Primary school & 262 & 49 \\
\hline & High school & 93 & 17 \\
\hline & License & 60 & 11 \\
\hline & Not literate & 26 & 5 \\
\hline \multirow{4}{*}{ Education Level of Father } & Primary school & 161 & 30 \\
\hline & Middle School & 109 & 20 \\
\hline & High school & 149 & 28 \\
\hline & Graduate & 118 & 22 \\
\hline \multirow{3}{*}{ Academic Achievement } & Low & 24 & 5 \\
\hline & Average & 299 & 56 \\
\hline & High & 214 & 40 \\
\hline \multirow[t]{2}{*}{ The financial situation of the family } & Average & 328 & 61 \\
\hline & Good & 185 & 35 \\
\hline
\end{tabular}


The majority of the students who participated in this study are female students. When we look at the distribution of the teacher candidates, most of them are studying in the fine arts and foreign language departments. When the educational status of parents is examined, it is seen that some of the candidates' mothers are not literate $(5 \%)$. The educational level of their mothers seems to be lower than their fathers. The academic achievement of students is mostly moderate and high. Given the financial situation of the family, it seems that the majority is moderate and good levels.

\section{Teacher Candidates' Attitudes towards Teaching Credentialing Courses}

Findings related to the attitudes of prospective teachers towards teaching profession courses are given in Table 2.

Table 2. Teacher Candidates' Attitudes towards Teaching Credentialing Courses

\begin{tabular}{|c|l|c|c|c|}
\hline \multicolumn{1}{|c|}{ Variable } & \multicolumn{1}{|c|}{ Department } & N & \multicolumn{1}{c|}{$\overline{\mathrm{X}}$} & $\mathrm{df}$ \\
\hline \multirow{5}{*}{$\begin{array}{c}\text { Teaching Credentialing } \\
\text { Courses }\end{array}$} & Physical education & 40 & 29.60 & .31 \\
\cline { 2 - 5 } & Fine Arts & 94 & 29.23 & .47 \\
\cline { 2 - 5 } & Computer Teaching & 59 & 29.76 & .36 \\
\cline { 2 - 5 } & \begin{tabular}{l} 
Special education \\
\cline { 2 - 5 }
\end{tabular} & 64 & 27.81 & .38 \\
\cline { 2 - 5 } & $\begin{array}{l}\text { Guidance and } \\
\text { Counseling }\end{array}$ & 73 & 28.56 & .46 \\
\cline { 2 - 5 } & $\begin{array}{l}\text { Foreign language } \\
\text { education }\end{array}$ & 90 & 29.30 & .33 \\
\cline { 2 - 5 } & Science Education & 50 & 29.50 & .40 \\
\cline { 2 - 5 } & $\begin{array}{l}\text { Primary school } \\
\text { teaching }\end{array}$ & 67 & 29.60 & .35 \\
\hline
\end{tabular}

I never agree $=10, \mathrm{I}$ do not agree $=20, \mathrm{I}$ agree little $=30, \mathrm{I}$ agree $=40, \mathrm{I}$ fully agree $=50$

In Table 2, it is seen that the teacher candidates are at the level of "I do not agree" regarding the teachers' credentialing course attitude scores. The average score of the lowest attitude belongs to the special education teachers $(\bar{X}=27.81)$, the highest attitude average score belongs to the candidate teachers in the Department of Computer Teaching $(\overline{\mathrm{X}}=29.76)$ and when evaluated in general, the scores of the teachers' attitudes to teaching profession are low. The standard deviations of the candidate teacher's opinions show that student opinions are similar.

\section{Teacher Candidates' Opinions Regarding the Behaviors of Instructors}

The opinions of the prospective teachers regarding the behaviors of instructors are given in Table 3 .
Table 3. Teacher Candidates' Opinions Regarding the Behaviors of Instructors

\begin{tabular}{|c|l|c|c|c|}
\hline Variable & \multicolumn{1}{|c|}{ Department } & $\mathrm{N}$ & $\overline{\mathrm{x}}$ & $\mathrm{df}$ \\
\hline \multirow{4}{*}{$\begin{array}{c}\text { Behaviors of } \\
\text { Instructors }\end{array}$} & Physical Education & 40 & 2.70 & .39 \\
\cline { 2 - 5 } & Fine Arts & 94 & 2.82 & .49 \\
\cline { 2 - 5 } & Computer Teaching & 59 & 2.74 & .42 \\
\cline { 2 - 5 } & Special Education & 64 & 2.67 & .44 \\
\cline { 2 - 5 } & Guidance and Counseling & 73 & 2.71 & .50 \\
\cline { 2 - 5 } & Foreign Language Education & 90 & 2.76 & .41 \\
\cline { 2 - 5 } & Science Education & 50 & 2.79 & .45 \\
\cline { 2 - 5 } & Primary School Teaching & 67 & 2.78 & .39 \\
\hline
\end{tabular}

In Table 3, it is seen that the prospective teachers' opinions about the behaviors of the instructors of the credentialing courses is mostly at an "adequate" level. The highest average is in the fine arts departments $(\bar{x}=2.82)$ and the lowest average is in the special education department $(\bar{x}=2.67)$.

4. Comparison of Teacher Candidates' Attitudes towards Credentialing Courses and Instructor Behavior According to Some Variables

The attitudes of the prospective teachers towards the credentialing courses and the behaviors of instructors were compared according to the variables of gender, department, economic status of the family, and education level of the parents.

\section{a) Gender:}

The results of the t-test on the comparison of the attitudes of the prospective teachers towards the credentialing courses and the views on the instructors' behaviors are given in Table 4.

Table 4. The comparison of the attitudes of the prospective teachers, towards the credentialing courses and the views on the instructors' behaviors

\begin{tabular}{|c|l|c|c|c|c|c|c|}
\hline Variable & \multicolumn{1}{|c|}{ Type } & $\mathrm{N}$ & $\overline{\mathrm{x}}$ & $\mathrm{S}$ & $\mathrm{df}$ & $\mathrm{t}$ & $\mathrm{P}$ \\
\hline \multirow{2}{*}{ MDT } & Male & 383 & 2.91 & .37 & \multirow{2}{*}{535} & 0.23 & .81 \\
\cline { 2 - 8 } & Female & 154 & 2.90 & .44 & & & \\
\hline \multirow{2}{*}{ ÖED } & Male & 383 & 2.71 & .43 & \multirow{2}{*}{535} & \multirow{2}{*}{1.47} & \multirow{2}{*}{.14} \\
\cline { 2 - 9 } & Female & 154 & 2.71 & .46 & & & \\
\hline
\end{tabular}

$\mathrm{P}>.05$

In Table 4, according to the gender variable, there is no difference among the attitudes of the prospective teachers, their attitudes towards the credentialing courses and the opinions about the behaviors of the instructors. 


\section{b) Department}

The results of one-way analysis of variance (ANOVA) on the comparison of the attitudes of the prospective teachers towards the credentialing courses and the instructors' behaviors according to the departments of the prospective teachers are given in Table 5 .

Table 5. Comparison of Teacher Candidate Opinions According to their Departments

\begin{tabular}{|c|c|c|c|c|c|c|}
\hline & Source of Variance & Sum of Squares & $\mathrm{df}$ & Mean Square & F-Ratio & $\mathrm{p}$ \\
\hline \multirow{3}{*}{ Attitudes towards the Credentialing courses } & Intergroup & 1,922 & 7 & 275 & \multirow{3}{*}{1,73} & \multirow{3}{*}{09} \\
\hline & Intra Groups & 83,484 & 529 &, 158 & & \\
\hline & Total & 85,405 & 536 & & & \\
\hline \multirow{3}{*}{ Instructors' behaviors } & Intergroup & 1,298 & 7 & , 185 & \multirow{3}{*}{,932 } & \multirow{3}{*}{,48 } \\
\hline & Intra Groups & 105,299 & 529 & ,199 & & \\
\hline & Total & 106,597 & 536 & & & \\
\hline
\end{tabular}

$\mathrm{p}>.05$

In Table 5, there is no difference between the opinions of prospective teachers, according to the departments, the attitudes of the credentialing courses and the opinions of the instructors.

\section{c) Maternal Education Status}

The results of the one-way analysis of variance (ANOVA) on the comparison of the attitudes of the prospective teachers towards the credentialing courses and the perceptions of instructor behaviors according to the maternal education status are given in Table 6.

Table 6. Comparison of Teacher Candidate Opinions According to Maternal Education Status

\begin{tabular}{|c|c|c|c|c|c|c|}
\hline & Source of Variance & Sum of Squares & df & Mean Square & F-Ratio & $\mathrm{p}$ \\
\hline \multirow{3}{*}{ Attitudes towards the Credentialing courses } & Intergroup & ,787 & 4 &, 197 & \multirow{3}{*}{, 123} & \multirow{3}{*}{29} \\
\hline & Intra Groups & 86,618 & 532 &, 159 & & \\
\hline & Total & 85,405 & 536 & & & \\
\hline \multirow{3}{*}{ Instructors' behaviors } & Intergroup & ,094 & 4 & 024 & \multirow{3}{*}{, 116} & \multirow{3}{*}{,97 } \\
\hline & Intra Groups & 106,503 & 532 & ,200 & & \\
\hline & Total & 106,597 & 536 & & & \\
\hline
\end{tabular}

According to Table 6, there is no difference between the attitudes of the prospective teachers about the credentialing courses and the opinions about the behaviors of the instructors according to the variables of Maternal Education Status.

\section{d) Educational Level of Father}

The results of one-way analysis of variance (ANOVA) on the comparison of the attitudes of the prospective teachers towards the credentialing courses and behaviors of the instructors according to the education level of the father are given in Table 7.

Table 7. Comparison of Teacher Candidate Opinions According to the Status of Father Education

\begin{tabular}{|c|c|c|c|c|c|c|}
\hline & Source of Variance & Sum of Squares & df & Mean Square & F-Ratio & $\mathrm{p}$ \\
\hline \multirow{3}{*}{ Attitudes towards the Credentialing courses } & Intergroup & 1,943 & 3 & ,648 & \multirow{3}{*}{4,13} & \multirow{3}{*}{, $00^{*}$} \\
\hline & Intra Groups & 83,462 & 533 &, 157 & & \\
\hline & Total & 85,405 & 536 & & & \\
\hline \multirow{3}{*}{ Instructors' behaviors } & Intergroup & ,204 & 3 &, 068 & \multirow{3}{*}{, 340} & \multirow{3}{*}{,79 } \\
\hline & Intra Groups & 106,394 & 533 &, 200 & & \\
\hline & Total & 106,597 & 536 & & & \\
\hline
\end{tabular}

$* \mathrm{p}<.05 \mathrm{p}>.05$

In Table 7, it is seen that the views of prospective teachers about their attitudes towards credentialing courses differ according to paternal educational status, while the opinions about the behaviors of instructors do not differentiate. Multiple comparisons were made to understand which groups differed. 
The LSD test results are given in Table 8, looking at the equality of variances between groups $[\mathrm{F}(3,533)=4,136, \mathrm{p}$ $<0.05]$.

Table 8. Multiple Comparison Results of Teacher Candidates' Attitudes towards Credentialing Courses According to Their Father's Educational Status

\begin{tabular}{|c|c|c|c|c|c|}
\hline & Father's Educational Status (I) & School Type (J) & Mean Difference (I-J) & Standard Error & $\mathrm{p}$ \\
\hline \multirow{3}{*}{ LSD } & \multirow{3}{*}{ Primary school } & Middle School &, 043 &, 049 &, 375 \\
\cline { 3 - 6 } & & High school &, 134 &, 044 &, 003 \\
\cline { 2 - 6 } & & Graduate &, 133 &, 047 &, 006 \\
\hline
\end{tabular}

$\mathrm{p}>.05 * \mathrm{p}<.05$

In Table 8, it is seen that the opinions of prospective teachers about their attitudes towards credentialing courses are significantly different between the individuals whose fathers have graduated from primary school, graduated from high school, and have college education.

e) Academic success

The results of a one-way analysis of variance (ANOVA) on the comparison of the attitudes of the prospective teachers to the credentialing courses and their perceptions of instructors' behaviors according to the academic achievement variable are given in Table 9.

Table 9. Comparison of Teacher Candidate Opinions According to Academic Achievement Status

\begin{tabular}{|c|c|c|c|c|c|c|}
\hline & Source of Variance & Sum of Squares & $\mathrm{df}$ & Mean Square & F-Ratio & $\mathrm{p}$ \\
\hline \multirow{3}{*}{ Attitudes towards the Credentialing courses } & Intergroup & 248 & 2 & ,124 & \multirow{3}{*}{,778 } & \multirow{3}{*}{,46 } \\
\hline & Intra Groups & 85,157 & 534 &, 159 & & \\
\hline & Total & 85,405 & 536 & & & \\
\hline \multirow{3}{*}{ Instructors' behaviors } & Intergroup & ,479 & 3 & ,239 & \multirow{3}{*}{1,204} & \multirow{3}{*}{,30 } \\
\hline & Intra Groups & 106,119 & 534 & , 199 & & \\
\hline & Total & 106,597 & 536 & & & \\
\hline
\end{tabular}

$\mathrm{P}>, 05$

In Table 9 there is no difference between the attitudes of the prospective teachers according to their success status, their attitudes towards credentialing courses and their views on the behaviors of the instructors.

\section{f) Financial Status of the Family}

The results of the one-way analysis of variance (ANOVA) for the comparison of the attitudes of the prospective teachers towards the credentialing courses and the instructors' behaviors according to the variable of the financial status of their families are given in Table 10.

Table 10. Comparison of Teacher Candidate Opinions According to the Financial Status Variable

\begin{tabular}{|c|c|c|c|c|c|c|}
\hline & Source of Variance & Sum of Squares & df & Mean Square & F-Ratio & $\mathrm{p}$ \\
\hline \multirow{3}{*}{ Attitudes towards the Credentialing courses } & Intergroup &, 045 & 2 & ,0232 & \multirow{3}{*}{, 141} & \multirow{3}{*}{, 86} \\
\hline & Intra Groups & 85,360 & 534 &, 160 & & \\
\hline & Total & 85,405 & 536 & & & \\
\hline \multirow{3}{*}{ Instructors' behaviors } & Intergroup & 1,7211 & 2 & ,605 & \multirow{3}{*}{3,067} & \multirow{3}{*}{, $04 *$} \\
\hline & Intra Groups & 105,387 & 534 &, 197 & & \\
\hline & Total & 106,597 & 536 & & & \\
\hline
\end{tabular}

$\mathrm{p}>.05 * \mathrm{p}<.05$

In Table 10, it is seen that the opinions of prospective teachers about their attitudes towards credentialing courses do not differ according to the financial status of the family, although their opinions about behaviors of instructors do differ in that respect. Multiple comparisons were made to understand which groups differed. The LSD test results are given in table 11 by looking at the equality of variances between groups $[\mathrm{F}(2,534)=3.067, \mathrm{p}<0.05]$. 
Table 11. Multiple Comparison Results According to the Variables of the Financial Status of the Teacher Candidates' Opinions on the Instructors' Behaviors

\begin{tabular}{|c|c|c|c|c|c|}
\hline & Financial Status of Family (I) & Financial Status (J) & Average Difference (I-J) & Standard Error & $\mathrm{p}$ \\
\hline \multirow{2}{*}{ LSD } & \multirow{2}{*}{ Poor } & Average & -.228 & .093 &, $01 *$ \\
\cline { 2 - 6 } & & Good & -.194 & .096 &, $044^{*}$ \\
\hline
\end{tabular}

$* \mathrm{P}<, 05$

Table 12. Results of Regression Analysis Regarding Prediction of Attitudes of Candidate Teacher Opinions to Credentialing Courses of Teacher Candidates

\begin{tabular}{|c|c|c|c|c|c|c|c|}
\hline Variable & $\mathrm{B}$ & Standard Deviation B & $\beta$ & $\mathrm{t}$ & $\mathrm{p}$ & $\begin{array}{c}\text { Binary } \\
\mathrm{r}\end{array}$ & $\begin{array}{c}\text { Partial } \\
\mathrm{R}\end{array}$ \\
\hline Constant & 25,77 & 1,07 & & 24.06 & .000 & \\
\hline Behaviors of Instructors & 1,22 &, 03 & .13 & 3.18 & .002 & .13 & .01 \\
\hline \multicolumn{2}{|c|}{$\mathrm{R}=.13, \mathrm{R}^{2}=.01, \mathrm{~F}=10.159, \mathrm{p}=.002$} \\
\hline
\end{tabular}

In Table 11, it is seen that the opinions of the prospective teachers about the behaviors of the instructors are significantly different among those financial status that are poor and the average and good, when the results of multiple comparisons are regarded according to the family financial status variable.

5. Whether Instructor Behaviors are a Predictor of Teacher Candidates' Attitudes towards Credentialing Courses

Table 12 shows the results of the regression analysis as to whether behaviors of instructors are a predictor of teacher candidates' attitudes towards credentialing courses.

When the findings in Table 12 are examined, there is a positive .13 relationship between the behaviors of the instructors and the attitudes of the prospective teachers to the credentialing courses $(\mathrm{R}=137)$, and $1 \%$ of the change in the dependent variable (credentialing course attitude) is explained by the modeled independent variable (behaviors of instructors). The model is found to be at a significant level $(\mathrm{F}=10.159, \mathrm{p}=.002)$. The parameters are found to be at a significant level $(\mathrm{t}=3.18, \mathrm{p}=.002)$. The regression model can be summarized by the following formula:

Teaching Profession Credentialing Courses $=25.77+1.22 \times$ Instructor Behaviors

\section{Discussion}

Findings obtained from comparing the attitude of teacher candidates towards credentialing classes and instructor behaviours, the attitudes of teacher candidates toward credentialing classes had low values. These results are similar to the findings of $(15 ; 16 ; 17 ; 19 ; 20 ; 2122)$, but contradict the findings of $(23 ; 24 ; 25 ; 59 ; 26)$. According to Er and Öztekin (2011) the reason for low attitudes of teacher candidates towards credentialing classes is inadequate credentialing class duration and lack of motivation. Özgüngör and Kapıkıran (2008) stated that art and music teachers had stated that credentialing classes had lower value than major related classes. Pehlivan (1994) stated that the level of meeting the credentialing and future expectations of teacher candidates with education programs could lead to changes in attitudes of teacher candidates. Thus, credentialing indifference of teacher candidates could lead to lower credentialing attitudes (1). According to Ekinci (2008) the most important factor for teacher candidates to develop positive attitude towards credentialing classes was to find learning styles under appropriate learning opportunities. When teacher candidates develop positive attitudes towards credentialing classes, they would attend these classes mote enthusiastically. Thus, they would be more positive towards their occupation. This was the first step for education quality and qualified teachers to be taken.

Another factor that affects attitudes of teacher candidates towards credentialing classes was the behaviour of instructors. The research found that behaviour of instructors had a significant effect on attitudes towards credentialing attitudes (39). In another research, instructor behaviours were emphasized as an important factor to reach learning objectives $(28 ; 29)$. Teacher candidates declared that instructor behaviours were adequate. These findings were in line with $(47 ; 48 ; 49 ; 50 ; 51 ; 52 ; 53 ; 69 ; 54)$ however, the findings were not in line with $(55 ; 38)$. According to students in the art-credentialing training department, the quality and attitude of instructors are one of the conditions that increase the quality in education-training (2). While instructors of credentialing classes will help teacher candidates love the occupation, they can also result in a negative attitude toward occupation. For this reason, instructors should be carefully selected and should be a model for teacher candidates. Based on the given information, credentialing class instructors should be selected from people who had previously worked as teachers and who know the area of teaching. Additionally, insufficient instructors should give the chance to update their knowledge and achieve development. Some of the studies claim the traditional teacher role of instructors are persistent and lack of personal update (62). There are other researchers that 
indicate competencies of instructors regarding teaching methods/techniques have low levels (45).

Based on the findings of this study, the relationship between low credential class attitudes of teacher candidates and sufficient instructor behaviour could be explained as follows: first, teacher candidates regard instructors as sufficient rather than extremely sufficient. On the other hand, behaviour of instructors is not the only factor that affects the attitudes of teacher candidates towards credentialing classes. Educational programs of the school, content of credential classes, and duration per week are among other factors.

Opinions of teacher candidates for attitude towards credentialing classes and perceiving the behaviour of instructor changed according to gender, department, academic success, education level of the mother. Thus, it could be said that teacher candidates have similar opinions. These findings are in line with literature for credentialing classes about teaching (20), and school experience classes in terms of gender $(33 ; 34 ; 35 ; 36)$ and department $(35)$.

Opinions of attitude of teacher candidates towards credentialing classes differentiated for education level of father. Teacher candidates that had father with elementary school education had positive difference compared to father with high school/undergraduate degree. Pehlivan (2008) stated that father with elementary school education had more positive difference than literate father.

Opinions of teacher candidates regarding instructor behaviours have significant differences in terms of monetary status of family. Teacher candidates in lower income families showed positive difference than medium/high income families. It could be said that teacher candidates in lower income families tolerated the behaviour of instructor more and perceived this behaviour as sufficient.

A positive and weak relationship between instructor behaviour and attitudes of teacher candidates towards credentialing classes were observed and instructor behaviours were determined as predictors for attitudes towards credentialing classes. According to Carr (2000), the lifestyle of instructors, credentialing applications, and attitudes and behaviours have significant effects on students. Effective credentialing classes stimulate positive affective features of teacher candidates (27). Although these findings seem to contradict the previous findings, it could be said that there is a positive relationship between attitudes of teacher candidates towards credentialing classes and behaviour of instructors. However, behaviour of instructors explained only the small portion of attitude of teacher candidates towards credential classes.

\section{Results and Suggestions}

When the attitudes of teacher candidates towards credentialing classes and the perception of instructor behaviour were investigated, the following results are obtained: credentialing attitudes of teacher candidates were found to be low. It should be reminded that teacher candidates who are indifferent for credentialing classes will be indifferent towards being a teacher. Teacher candidates declared that instructor behaviours were adequate. However, the level is not strongly adequate. There was weak relationship between low attitude of teacher candidates towards credentialing classes and behaviour of instructors. The reason has been estimated as different variables that affect credentialing attitudes of teacher candidates. Based on these results, the underlying reasons for lower attitude of teacher candidates towards credentialing classes should be investigated. Although opinions of teacher candidates were insignificant in terms of gender, department, academic success, and education level of mother, there were significant differences in terms of education level of father and monetary status of family. As the education level of the participants' fathers and income of family increased, attention towards credentialing classes decreased.

A positive and low relationship between instructor behaviours and attitudes of teacher candidates towards credentialing classes were determined and instructor behaviours were set as predictors. Behaviours of instructor variable should consider as an effective factor to increase the attention towards credentialing classes. Based on these results, following suggestions were made: The behaviour of instructors should be promoted to become extremely sufficient. The reasons for low attitude of teacher candidates towards credentialing classes could be investigated with qualitative analysis. In this study, attitudes towards multiple credentialing classes were considered. Future studies could handle the attitudes for each class separately. Similar researches could be conducted in different universities and the results could be compared with this study.

\section{REFERENCES}

[1] Türker, N. and Turanl, N. (2008). Development of attitude scale for mathematics education courses. Gazi University, Journal of Gazi Education Faculty, 28 (3), 17-29.

[2] Buyurgan, S. (2007). Faculty of education pictures - job descriptions students' acceptance education and teachings views and expectations, Journal of Turkish Educational Sciences, 5(4), 657-677.

[3] Erginer, E. and Dursun, F. (2005). Instructors' Views Towards Developing Effective Teaching Skills, Education and Science, 30 (135), 11-22.

[4] Medley, D. M. (1982).Teacher Competency Testing and the Teacher Educator, Association of Teacher Educators and the Bureau of Educational Research in Charlottesville, 1-43. 
[5] Ministry of Education (2008). Teaching Proficiency, Teaching Profession General and Special Field Qualifications. Ankara: Ministry of Education Publications.

[6] Brauer, J. (2010). Teacher Creativity and Teacher Professional Competency, Teacher/Mentor, 1-22.

[7] Mangin, M.M \& Stoelinga, S.R (2010). The Future of Instructional Teacher Leader Roles, The Educational Forum, Kappa Delta Pi, 74, 49-62.

[8] Hawley, W. D., and L. Valli. (1999). The Essentials of Effective Professional Development. In Teaching as the Learning Profession: Handbook of Policy and Practice, ed. L. Darling Hammond and G. Sykes, 127-50. San Fran cisco: Jossey-Bass., II, 257-275

[9] Garet, M. S., A. C. Porter, L. Desimone, B. F. Birman, and K. S. Yoon. (2001). What Makes Professional Development Effective? Results from a National Sample of Teachers. American Educational Research Journal, 38(4): 915-45.

[10] Richardson, V., \& Placier, P.(2001). Teacher Change in Handbook of Research on Teaching, 4th ed. , ed . V. Richard son, 905-47. New York: Macmillan.

[11] Hallman, S.R., S.A. Wenzel and C.R. Fendt, C.R. (2004). Interim evaluation report: CMSI/CUSP elementary school development. Report B: The specialist report. Chicago: UJC CMSI Evaluation Project.

[12] Varıș, F. (1988). Curriculum Development in Education. Ankara University, Faculty of Education Publications. Ankara.

[13] TED (2009). Teacher Competencies, Turkish Education Association Publications, Ankara.

[14] Taşkın, Ç., Ş. and Haciömeroğlu, G. (2010). Importance of Pedagogy Courses on Preservice Teachers' Professional Development, Pamukkale University Education Faculty Journal, 28 (2), 165-174.

[15] Kara, D., A and Sağlam, M. (2014). Evaluation of Professional Teaching Knowledge Courses in Terms of Competencies Regarding the Learning and Teaching Process, Journal of Qualitative Research in Education -ENAD, 2 (3), 28-86.

[16] Güleç, D., G. (2012). Determination of pre-service teachers perceptions on the teaching certificate courses, M.Sc. Thesis, Mehmet Akif Ersoy University, Institute of Social Sciences, Department of Educational Sciences

[17] Işıkgöz, E., Dinçer, N., Kılınç, Z. (2016). Investigation of the Relationship Between Physical Education Teacher Candidates' Content Knowledge and Pedagogical Knowledge Achievement in Classes(Case of Batman University), Batman University Journal of Life Sciences; 6 $(2 / 1), 338-346$

[18] Jangira, N.K. (1979). Teacher Training and Teacher Effectiveness, National Publishing House, New Delhi

[19] Erden, M. (1995). Teacher Candidates' Attitudes towards Teaching Certificate Courses. Hacettepe University Journal of Education, 11, 99-105.

[20] Er, K. O and Öztekin, A. (2011). Investigation of Attitudes of Teacher Candidates Towards Teaching Credentialing Knowledge Courses, I. International Education Programs and "Education Congress, Eskisehir: Anadolu University.

[21] Cetin, F. (2009). Attitudes of the Faculty of Education Students towards Teaching Credentialing Courses, Gazi University Industrial Arts Education Faculty Magazine, 25, 58-64.

[22] Özgüngör, S and Kapıkıran, Ş. (2008). Motivation and Achievement Levels Related to Teaching Credentialing Knowledge Courses of Fine Arts Education Students, Pamukkale University Journal of Education, 1, 47-60.

[23] Buluç, B. (2002). Attitudes Towards Teaching Certificate Programs of Primary School Teachers Department Students, Journal of Social Thought, 3 (5), 41-48.

[24] Saracaloğlu, A. S., Serin, O., Bozkurt, N., Serin, U. (2004). Factors Affecting Teacher Candidates' Attitudes towards Jobs. Contemporary Education, 29(311), 16-27. [25]

[25] Aslan, D. and Akyol, A.K. (2006). Examination of preschool teacher candidates' attitudes towards the teaching profession and their professional self-esteem CU Journal of Social Sciences Institute, 15, 51-60.

[26] Terzi, A., R. and Tezci, E. (2007). The Attitudes of the Students towards Teaching Profession at Necatibey Education Faculty, Theory and Practice in Education Management, 52, 593-614.

[27] Som, İ, Türkan, A. and Altun, S. (2016). Design of Introduction to Educational Sciences Course Using UbD: The Evaluation of Prospective Teachers' Achievement, Attitudes and Opinions About the Course, International Journal of Social Sciences and Education Research, 2 (4), 1659-1672, Online, http://dergipark.gov.tr/ijsser, 2 (4), $1659-1672$

[28] Güçlü, N. (2000). Teacher Behaviors, National Education Journal, 147, 21-23.

[29] Terzi, A. R. (2002). Effective teacher behaviors in terms of classroom management .National Education Journal, 155-156.

[30] Strang, F.A. (1995). An Analysis of Self-Ratings of Teaching Competencies and Stressors of Student Teaching Interns, Unpublished Thesis, Memorial university of Newfoundland.

[31] PGG (2011). Professional Growth Guide for Teacher Candidates Student Teaching and Internship 2010-2011, College of Education Annual Research Report: 2011-2012, $1-28$.

[32] Mangin, M.M \& Stoelinga, S.R (2010). The Future of Instructional Teacher Leader Roles, The Educational Forum, Kappa Delta Pi, 74, 49-62.

[33] Riza E.and Hamurcu H. (2000). Classroom Teaching Students' Opinions about School Experience and Teaching Practice. Pamukkale University Education Faculty Journal, 8 (ÖzelSay1), 1-8.

[34] Güzel, H. and Oral, İ. (2008). A study on the school experience activities of students of the faculty of education faculty department of S.U. Selçuk university Ahmet Keleşoğlu Journal of Education, 25, 249 -261.

[35] Yildiz, E. (2002). Evaluation of school experience I and school experience II lessons. Unpublished Master's Thesis, 
Sakarya University Social Sciences Institute, Sakarya.

[36] Ören, F., Ö, Sevinç, Ö., S. And Erdoğmuş, E. (2009). Assessing Teacher Candidates' Attitudes and Views towards School Experience Courses, Educational Administration in Theory and Practice. 15 (58), 217-246.

[37] Higher Education institution (2017). Ethical Code of Conduct for Higher Education Institutions, Access: 6.3.2017http://kurul.odu.edu.tr/files/akademik-etik-ilkeler.p df

[38] Kumral, A (2009). Prospective Teachers' Perceptions of Instructors' Behaviors Pamukkale University, Journal of Education, 25, 92-102.

[39] Carr, D. (2000). Professionalism and ethics in teaching. Taylor \& Francis or Routledge, N. York.

[40] Özcan, K. and Balyer, A. (2012). Academic Staff, Adaptation of Ethical Behavior Scale to Turkish, Adiyaman University Institute of Social Sciences, Journal, 5(10), 345-376.

[41] Elçi, A. and Yaratan, H. (2012). Professional Development Needs in Teaching and Learning at an International University, Eurasian Journal of Educational Research, 49/A,(47-66).

[42] Riza E. and Hamurcu H. (2000). Classroom Teaching Students' Opinions about School Experience and Teaching Practice. Pamukkale University Education Faculty Journal, 8 (special issue), 1-8.

[43] Kara, A.; İzci, E.; Köksalan, B. and Zelyurt, H. (2015). Development Of Perceived Instructor Behaviors Scale, The Journal of International Lingual, Social and Educational Sciences, 1(1), 21-32

[44] Ekici, G. (2008). Evaluation of The Attitudes of Teacher Candidates' towards Teachıng Certıficate Courses and Their Learnıng Modalıtıes, Yüzüncü Yıl University, Journal of Education Faculty, 5 (1): 111-132

[45] Bozpolat, E., Uğurulu, C. T., Usta, H. G. and Şimşek, A.S. (2016). Views of Student and Teaching Staffs Regarding Teaching Method and Techniques: A Qualitative Research, Dicle University Ziya Gökalp Education Faculty Journal, 27, (83-95).

[46] Hacioğlu, F and Alkan, C (1995). Teaching Practices and Teaching Technology, İstanbul: Alkım Publications.

[47] Bayram, H. (1992). Instructor-Student Communication in Higher Education in Educational Field, Unpublished master's thesis, Gazi University, Institute of Social Sciences, Ankara

[48] Bolat, S. (1990). Instructor-Student Communication in Higher Education, Unpublished Master's Thesis, Hacettepe University, Institute of Social Sciences,

[49] Deryakullu, D. (1992). The Factors Preventing Display of Required Behavior Concerning Teacher-Student Communication., Unpublished Master's Thesis, Ankara University, Institute of Social Sciences,

[50] Erdoğan, Ö. (1990). Evaluation of Instructional Membership in Terms of Learning and Teaching Processes, Unpublished Master's Thesis, Hacettepe University, Institute of Social Sciences, Ankara.
[51] Erginer, A. (1997). AİBÜ Faculty of Education Department of Teaching Proficiency of Instructors in Department of Teaching, Unpublished Master Thesis, Abant Izzet Baysal University, Institute of Social Sciences.

[52] Gömleksiz, M. (1988). Evaluation of the Behaviors of Academic Staff and Students of Hacettepe University in terms of a Democratic Classroom Environment, Unpublished Master Thesis, Hacettepe University, Institute of Social Sciences, Ankara.

[53] Gözütok, F. D. (1988). Reflection of Teacher Training in the Formation of Occupation Formation to the Behavior of Instructor, Unpublished Doctorate Thesis, Ankara University Institute of Social Sciences, Ankara

[54] Türkoğlu, A. (1993). Problems in Educational School Curriculums. First National Reports of Educational Sciences (179-189). Ankara University Educational Sciences \& National Education Printing House.

[55] Şen, H., Ş and Erişen Y. (2002). Effective Teaching Specialties of Teacher Trainers Working at Teacher Training Institutions, Gazi University Gazi Education Faculty Journal, 22 (1), 99-116.

[56] Ulusavaş, M. \& Nas, R. (1990). A Study on Teachers' Instructors in Education Faculties. Teacher's World Magazine, 131, 15-18.

[57] Higher Education Board (2014). Procedures and Principles for the Pedagogical Formation Education Certificate Program, Access: 6.3. 2017

[58] Er, K. O and Öztekin, A. (2011). Investigation of Attitudes of Teacher Candidates Towards Teaching Credentialing Knowledge Courses, I. International Education Programs and "Education Congress, Eskisehir: Anadolu University.

[59] Aladağ, C. and Buldur, D. (2016). Competences Level of Prospective Geography Teachers For Their Field, IJOESS, Year: 7, Vol: 7, Issue: 25, 70-86.

[60] Demir, M. K. (2004) Investigation of Mathematical Attitudes of Class Teacher Candidates, Educational Researches, 14, 162-170.

[61] Pehlivan, H. (1994) Attitudes of Students of Educational Sciences towards Their Departments. Hacettepe University Education Faculty Magazine, 10, 49-53.

[62] Aksu, M. B., Çivitçi, A. and Duy, B (2008). College Students' Perceptions about Teaching Practices, Classroom Behaviors and Attitudes of the Faculty Members, İnönü University Journal of the Faculty of Education, 9(16), 1742 .

[63] Çetin, F. (2009). Attitudes of the Faculty of Education Students towards Teaching Credentialing Courses, Gazi University Industrial Arts Education Faculty Magazine, 25, 58-64.

[64] Bhattacherjee, A. (2012). Social Science Research: Principles, Methods, and Practices, Textbooks Collection. Book 3, Access: 6.3.2017 http://scholarcommons.usf.edu/oa_textbooks/3

[65] Durmuş, S. and Nartgün, Z. (2003). Teaching staff assessment scale, Abant İzzet Baysal University, Journal of Social Sciences Institute, 2 (7), 49-56. 
[66] George, D. veMallery, M. (2010). SPSS for Windows Step by Step: A Simple Guide and Reference, 17.0 update (10a ed.) Boston: Pearson.

[67] Gravetter, F., \& Wallnau, L. (2014). Essentials of statistics for the behavioral sciences (8th ed.). Belmont, CA Wadsworth.http://www.yok.gov.tr/web/guest/icerik/-journa 1 contet56 INSTANCE rEHF8BIsfYRx/10279/7052802,
[68] Pehlivan, K. (2008). A study on the socio-cultural characteristics of classroom teacher candidates and their attitudes towards teaching profession. Mersin University Education Faculty Journal, 4 (2), 151-168.

[69] Kavak, Y. (1986). The Competencies and Training Needs of the Faculty of Education, Unpublished $\mathrm{PhD}$ Thesis, Hacettepe University, Institute of Social Sciences, Ankara. 